\title{
PENGARUH MEKANISME CORPORATE GOVERNANCE, KINERJA LINGKUNGAN DAN PENGUNGKAPAN LINGKUNGAN PERUSAHAAN TERHADAP REAKSI PASAR
}

\author{
Bayu Tri Prasetio Mukti \\ (Direktorat Jenderal Pajak) \\ Email: iam.bmukti@gmail.com
}

\section{Made Sudarma \\ Grahita Chandrarin}

(Program Pascasarjana Fakultas Ekonomi dan Bisnis Universitas Brawijaya)

\begin{abstract}
The purpose of this study was to analyze the market reaction as indicated by rising the stock price as a result of the implementation corporate governance mechanisms, environmental performance and corporateenvironmental disclosure published on the annual report in 2010. This study uses hypothesis testing approach to explain the causal relationship between the variables of the study. The population in this study is a registered company in Indonesia Stock Exchange. The results show that the application of corporate governance mechanism through the principles of good corporate governance has a significant effect on the market reaction that is proxied by stock prices. The tests performed on the environment performance and environment disclosure which is proxied by the Rating of Company Performance in Environmental Management (PROPER) and the Indonesian Sustainability Reporting Award (ISRA) found that there is no significant effect on the market reaction that is proxied by stock prices.
\end{abstract}

Keywords: Corporate Governance, Environmental Performance, Environmental Disclosure, and Stock Price.

\footnotetext{
Abstrak

Tujuan penelitian ini adalah untuk menganalisis reaksi pasar yang ditunjukkan dengan meningkatnya harga saham sebagai akibat dari penerapan mekanisme corporate governance, publikasi pemeringkatan kinerja lingkungan
} 
dan publikasi pemeringkatan pengungkapan lingkungan perusahaan pada saat publikasi laporan tahunan tahun 2010. Penelitian ini menggunakan pendekatan hypotesis testing untuk menjelaskan hubungan kausal antara variabel-variabel penelitian. Populasi dalam penelitian ini adalah perusahaan yang terdaftar di Bursa Efek Indonesia. Hasil pengujian menunjukkan bahwa penerapan mekanisme corporate governance melalui prinsip-prinsip good corporate governance memiliki pengaruh yang signifikan terhadap reaksi pasar yang diproksikan dengan harga saham. Pengujian yang dilakukan terhadap aspek lingkungan sosial perusahaan yaitu kinerja lingkungan dan pengungkapan lingkungan perusahaan yang masing-masing diproksikan oleh Peringkat Kinerja Perusahaan Dalam Pengelolaan Lingkungan Hidup (PROPER) dan Indonesian Sustainability Reporting Award (ISRA) belum mampu menunjukkan adanya pengaruh yang signifikan terhadap reaksi pasar yang diproksikan dengan harga saham.

Kata Kunci: Corporate Governance, Kinerja Lingkungan, Pengungkapan Lingkungan, dan Harga Saham

\section{PENDAHULUAN}

Pembahasan mengenai pasar modal tidak akan terlepas dari informasi. Para pelaku pasar modal membutuhkan informasi dalam pengambilan keputusan investasi. Informasi dapat mengurangi ketidakpastian yang terjadi, sehingga keputusan yang diambil diharapkan akan sesuai dengan tujuan yang ingin dicapai (Fatmawati dan Asri, 1999). Informasi yang dibutuhkan bukan hanya sekedar informasi, tetapi informasi yang informatif, artinya informasi tersebut dapat digunakan sebagai pedoman dalam pengambilan keputusan.

Foster (1986) menyatakan ada tiga faktor yang mempengaruhi kandungan informasi dari suatu pengumuman informasi perusahaan. Pertama, ekspektasi pasar terhadap kandungan dan ketepatan waktu (timing) dari pengumuman informasi perusahaan. Semakin besar tingkat ketidakpastian, maka semakin besar potensi terjadinya revisi terhadap harga-harga sekuritas. Kedua, implikasi dari pengumuman laba terhadap distribusi return sekuritas di masa depan. Semakin besar revisi yang berhubungan dengan aliran kas yang diharapkan, semakin besar pula implikasi revaluasi 
harga sekuritas terhadap pengumuman tersebut. Ketiga, kredibilitas sumber informasi. Semakin kredibel sumber pengumuman informasi, semakin besar pula implikasi revaluasi terhadap pengumuman informasi itu.

Perhatian investor lebih sering terpusat pada informasi laba tanpa memperhatikan prosedur yang digunakan untuk menghasilkan laba tersebut (Beattie, et al; 1994). Hal ini disebabkan karena laba adalah parameter yang sangat mudah dipahami oleh investor untuk menilai kinerja dari suatu perusahaan, hal ini sejalan dengan Hendricksen dan Van Breda (1992:123) yang menyatakan bahwa informasi laba atau laba historis berguna untuk mengukur efisiensi manajemen, membantu memprediksi keadaan usaha dan distribusi dividen di masa yang akan datang, mengukur keberhasilan manajemen, serta sebagai acuan pengambilan keputusan ekonomis di masa yang akan datang. Scott (2000) menambahkan bahwa informasi laba dapat berguna jika dapat mengakibatkan investor mengubah keyakinan dan tindakan sebelumnya dan tingkat kegunaan tersebut dapat diukur dari sejauh mana perubahan harga mengikuti publikasi informasi laba.

Terjadinya kecenderungan investor dan pihak eksternal lainnya yang lebih berfokus pada informasi laba, memicu manajemen melakukan disfunctionalbehaviour berupa manajemen laba (earning management) atau manipulasi laba (earnings manipulation) untuk menghasilkan laba yang dianggap normal bagi suatu perusahaan (Bartov, 1993).

Upaya yang dapat dilakukan untuk menciptakan laba yang normal adalah melalui penerapan corporate governance. Karena corporate governance merupakan suatu cara untuk menjamin bahwa manajemen bertindak yang terbaik untuk kepentingan stakeholders. Pelaksanaan good corporate governance menuntut adanya perlindungan yang kuat terhadap hak-hak pemegang saham, terutama pemegang saham minoritas. Prinsip-prinsip atau pedoman pelaksanaan good corporate governance (GCG) menunjukkan adanya perlindungan tersebut, tidak hanya kepada pemegang saham, tetapi meliputi seluruh pihak yang terlibat dalam perusahaan termasuk masyarakat.

Jensen dan Meckling (1976) serta Morck (1988) menyatakan bahwa mekanisme corporate governance dapat meningkatkan kualitas pelaporan keuangan yang salah satunya akan tercermin dalam kualitas labanya. Kualitas laba dapat diuji salah satunya dengan melihat sejauh mana laba memiliki hubungan atau dapat menjelaskan nilai pasar yang diproksikan dengan harga dan return saham. Laba dapat dikatakan berkualitas 
tinggi apabila laba yang dilaporkan dapat digunakan oleh para pengguna dalam pengambilan keputusan yang terbaik, dan dapat digunakan untuk menjelaskan atau memprediksi harga dan return saham (Bernard dan Stober, 1989).

Berdasarkan beberapa penjelasan di atas, tampak bahwa mekanisme corporate governance terbukti mampu menjadi alat bagi perusahaan untuk memberikan informasi kepada investor bahwa suatu perusahaan akan memberikan return yang diharapkan oleh investor. Dan dari sisi investor, adanya informasi mengenai komitmen perusahaan dalam penerapan corporate governanceakan memberikan nilai tambah (value added) tersendiri bagi perusahaan tersebut di mata investor. La Portaet al. (2002) menjelaskan bahwa perlindungan terhadap investor dalam bentuk penerapan corporate governanceakan meningkatkan nilai pasar. La Portaet al. (2002) menyebutkan bahwa investor akan membayar lebih atas perlindungan yang diberikan kepada investor, karena laba yang dihasilkan oleh perusahaan akan kembali lagi ke investor dalam bentuk bunga ataupun dividen. Neal dan Cochran (2008) mendukung hal tersebut, yang menyatakan bahwa good corporate governance sangat bernilai pada pasar modal dan investor akan membayar lebih atas perusahaan-perusahaan yang menerapkan prinsip-prinsip corporate governance.

Black (2001) menguji hubungan corporate governance dan nilai pasar pada perusahaan-perusahaan yang ada di Rusia. Hasil penelitiannya menunjukkan bahwa memang terdapat hubungan antara corporate governance dengan nilai pasar. Hasil ini juga didukung oleh penelitian yang dilakukan oleh Brown dan Caylor (2006), penelitian ini memberikan implikasi bahwa para pelaku investasi di pasar Rusia dapat menggunakan corporate governance sebagai informasi dalam pengambilan keputusan investasi.

Klapper dan Love (2004) menguji hubungan antara corporate governance, perlindungan investor, dan kinerja pada pasar yang berkembang (emerging market). Hasil penelitiannya menunjukkan bahwa terdapat hubungan antara corporate governance dengan market valuation dan kinerja. Dalam penelitiannya, tingkat corporate governance perusahaan menjadi sesuatu yang penting pada negara-negara dengan tingkat perlindungan investor yang rendah. Sistem hukum tidak terlalu penting bagi perusahaan-perusahaan yang corporate governance-nya bagus, hal ini beralasan karena perusahaan dengan tata kelola yang bagus hanya sedikit bergantung pada sistem 
hukum dalam penyelesaian permasalahan corporate governance-nya. Hasil penelitian ini mendukungLa Portaet al. (2002).

Tristiarini (2005) menguji pengaruh corporate governance terhadap abnormal return pada saat pengumuman laporan keuangan. Penelitian ini menggunakan empat prinsip corporate governance yaitu transparansi, kewajaran, akuntabilitas, dan responsibilitas. Hasil penelitiannya menemukan bahwa penerapan corporate governance yang tercermin dari keempat prinsip diatas memiliki pengaruh yang signifikan terhadap abnormal return. Hal ini menunjukkan bahwa corporate governance memberikan pengaruh pada investor dalam memilih emiten atau saham yang akan dibeli.

Saat ini perhatian investor tidak lagi hanya tertuju pada corporate governance saja dalam menghasilkan laba normal sebagai dasar pengambilan keputusan investasi. Belkaoui (1976:26-31) dan Patten (1990) menyatakan bahwa dalam proses pengambilan keputusan investasi, investor memasukkan variabel yang berkaitan dengan masalah sosial dan kelestarian lingkungan.

Elkington pada tahun 1997 dalam bukunya "Cannibals with Forks, the Tripple Bottom Line of Twentieth Century Business" mengembangkan konsep triple bottom line dalam istilah economic prosperity, environmental quality dan social justice. Elkington memberikan pandangan bahwa jika suatu perusahaan ingin bertahan (going concern) maka perusahaan tersebut harus memperhatikan "3P”. Disamping perusa-haan bekerja keras untuk mendapatkan keuntungan (profit), perusahaan juga harus memperhatikan dan terlibat pada pemenu-han kesejahteraan masyarakat (people) dan juga harus berkontribusi aktif untuk menjaga kelestarian lingkungan (planet).

Keberlanjutan perusahaan hanya akan terjamin apabila, perusahaan memperhatikan dimensi sosial dan lingkungan hidup. Sudah menjadi fakta bagaimana resistensi masyarakat sekitar, di berbagai tempat dan waktu muncul ke permukaan terhadap perusahaan yang dianggap tidak memperhatikan aspek-aspek sosial, ekonomi dan lingkungan hidupnya.

Budiman dan Supatmi (2009) melakukan pengujian keterkaitan antara CSR dengan reaksi investor melalui uji pengaruh antara variabel-variabel yang diuji. Indonesia Sustainability Reporting Award (ISRA) digunakan sebagai proksi dari CSR, dan untuk menilai reaksi investor, digunakan dua variabel yaitu abnormal return dan 
volume perdagangan saham. Dari hasil pengujiannya menunjukkan bahwa terdapat pengaruh signifikan pengumuman ISRA terhadap abnormal return, tetapi tidak menunjukkan pengaruh signifikan terhadap volume perdagangan saham.

Pengujian mengenai aspek sosial juga dilakukan oleh Al-Tuwaijri, Christensen, dan Hughes II (2004), Penelitian tersebut menggunakan pengungkapan lingkungan, kinerja lingkungan, dan kinerja keuangan untuk menguji hubungan antara ketiganya. Dari hasil pengujiannya menunjukkan bahwa terdapat hubungan positif signifikan antara pengungkapan lingkungan dengan kinerja lingkungan, dan kinerja lingkungan dengan kinerja ekonomi.

Berdasar beberapa penelitian terdahulu, penelitian ini berusaha untuk melakukan pengujian yang lebih update dan komprehensif. Dalam penelitian ini dilakukan pengujian terhadap tiga aspek yaitu aspek internal perusahaan, aspek lingkungan sosial dan aspek reaksi pasar.

\section{TINJAUAN PUSTAKA DAN HIPOTESIS}

Grand theory tentang reaksi pasar terhadap kandungan informasi mengacu pada dua peneliti, yaitu Ball dan Brown dan Beaver. Penelitian yang mempelajari reaksi pasar pertama kali dilakukan oleh Ball dan Brown (1968). Parameter yang digunakan oleh Ball dan Brown (1968) untuk mengetahui reaksi pasar adalah menggunakan return dan abnormal return. Return dihitung dengan harga periode t dikurangi dengan harga papa periode t-1. Abnormal return dihitung dengan return perusahaan i dikurangi dengan return portofolio. Tujuan Ball dan Brown (1968) adalah mengetahui pengaruh perubahan informasi laba terhadap perilaku investor. Laba tersebut diklasifikasikan menjadi dua, yaitu kenaikan laba (good news) dan penurunan laba (bad news). Data yang digunakan adalah data pengumuman laporan keuangan di New York Stock Exchange periode 1957 - 1965, dengan jumlah sampel sebanyak 261 perusahaan. Hasil penelitiannya ditemukan bahwa terdapat pengaruh informasi perubahan laba dan aliran kas terhadap abnormal return. Pasca publikasi laporan keuangan, indeks saham mendatar sampai dengan bulan keenam.

Penelitian berikutnya yang menguji tentang reaksi pasar dilakukan oleh Beaver (1968) yang meneliti pengaruh kandungan informasi laporan keuangan terhadap terhadap volume perdagangan dan pergerakan harga saham. Penelitian ini lebih 
menekankan pada faktor-faktor non earning yang mendorong volume perdagangan pada saat pengumuman earning. Sampel dipergunakan sebanyak 143 perusahaan dengan periode 1961-1965 yang dibatasi pada perusahaan yang tidak mengumumkan dividen pada saat minggu earning tahunan diumumkan, sehingga dampak dari salah satu nonearning potensial mendorong volume perdagangan menjadi minimum. Beaver (1968) meneliti volume perdagangan mingguan selama 17 minggu dan melaporkan terjadi kenaikan volume yang agak dramatis pada saat minggu pengumuman (minggu 0). Ratarata volume perdagangan pada minggu 0 adalah 33\% lebih besar dibandingkan rata-rata volume selama periode non laporan, yang juga merupakan nilai observasi terbesar selama 17 minggu pengamatan. Investor menggeser posisi portofolio pada saat pengumuman earning dan pergeseran ini konsisten dengan isi laporan earning mempunyai kandungan informasi yang memuaskan. Earnings laporan berhubungan dengan peristiwa yang mendasari yang dipersepsikan oleh investor untuk mempengaruhi harga pasar.

Beberapa peneliti menguji pengaruh dari corporate governance terhadap reaksi pasar. Arifin (2003) menemukan bahwa pengumuman earnings yang dilakukan oleh perusahaan yang bagus CG-nya tidak secara signifikan meningkatkan value relevance dari pengumuman earnings, namun secara signifikan menurunkan divergensi ekspektasi investor. Hal ini terbukti dengan TVA yang signifikan lebih kecil dibandingkan dengan perusahaan yang kurang bagus CG-nya. Almilia dan Sifa (2006) juga menggunakan Corporate Governance Perception Index (CGPI) untuk menguji reaksi pasar. Hasil penelitian membuktikan bahwa pengumuman CGPI pada perusahaan kelompok sepuluh besar dan kelompok non sepuluh besar direaksi oleh pasar yang ditunjukkan dengan adanya abnormal returnyang signifikan disekitar tanggal pengumuman. Temuan berikutnya adalah tidak terdapat perbedaan abnormal return dan volume perdagangan yang signifikan pada saat pengumuman CGPI antara perusahaan yang masuk sepuluh besar dan non-sepuluh besar CGPI.

Menggunakan prinsip-prinsip GCG dalam penelitian, Tristiarini (2005) menemukan bahwa penerapan prinsip-prinsip GCG berpengaruh terhadap terjadinya abnormal return sebagai reaksi positif dari investor.

Prinsip transparansi, perusahaan harus menyediakan informasi yang material dan relevan dengan cara yang mudah diakses dan dipahami oleh pemangku kepentingan, 
serta memiliki inisiatif untuk mengungkapkan tidak hanya masalah yang disyaratkan oleh peraturan perundang-undangan, tetapi juga hal yang penting untuk pengambilan keputusan oleh pemegang saham, kreditur dan pemangku kepentingan lainnyaGood Corporate Governance (KNKG, 2006:5-7).

Tingkat pengungkapan informasi merupakan tingkat kelengkapan dan komprehensifitas penyajian informasi perusahaan (Junaedi, 2005). Semakin banyak informasi yang diungkapkan oleh perusahaan ke publik berarti bahwa perusahaan telah menerapkan CG dan berharap pasar akan merespon positif sehingga harga saham semakin meningkat. Ismail, Arshad dan Othman (2012) menyatakan bahwa transparansi berpengaruh terhadap harga saham. Transparansi perusahaan yang lebih tinggi merefleksikan bahwa good governance sedang dilakukan oleh perusahaan. Junaedi (2005) menyatakan bahwa tingkat komprehensifitas informasi yang terkandung dalam laporan tahunan memiliki pengaruh yang signifikan terhadap volume perdagangan saham, akan tetapi hanya menghasilkan signifikansi yang lemah terhadap abnormal return.

Peningkatan terhadap volume perdagangan saham menunjukkan bahwa permintaan atas suatu saham meningkat. Sejalan dengan teori pasar, maka peningkatan terhadap volume perdagangan akan berdampak pada peningkatan harga.Berdasarkan penjelasan di atas, hipotesis yang diajukan adalah sebagai berikut:

$\mathrm{H}_{1 \mathrm{a}}$ : Pengungkapan prinsip transparansi berpengaruh terhadap reaksi pasar.

Prinsip kewajaran yang dimaksud adalah kewajaran dari penyajian laporan keuangan perusahaan. Kewajaran tersebut terlihat dari adanya opini yang diberikan oleh akuntan publik. Meiden (2008) menyatakan bahwa opini audit sangat penting sebagai acuan bagi para investor untuk melakukan kegiatan investasi, opini yang dikeluarkan oleh auditor selain wajar tanpa pengecualian membuat para investor ragu-ragu untuk melakukan investasi karena hal ini selain akan mempengaruhi harga saham juga dapat mempengaruhi return saham.

Berdasarkan penjelasan di atas, hipotesis yang diajukan adalah sebagai berikut: H1b: Pengungkapan prinsip kewajaran berpengaruh terhadap reaksi pasar. 
Fama dan Jensen (1983) menyatakan bahwa non-executive director (komisaris independen) dapat bertindak sebagai penengah dalam perselisihan yang terjadi di antara para manajer internal dan mengawasi kebijakan manajemen serta memberikan nasihat kepada manajemen. Komisaris independen memainkan peranan yang aktif dalam peninjauan kebijakan dan praktik pelaporan keuangan. Komisaris independen diperlukan untuk memantau dan mengawasi tindakan dewan direksi karena perilaku opportunistik (Jensen dan Meckling, 1976).

Untuk memastikan bahwa prinsip-prinsip GCG telah dilaksanakan dengan baik maka diperlukan suatu pihak yang dapat menjaga akuntabilitas perusahaan. Badan Pengawas Pasar Modal dan Lembaga Keuangan (BAPEPAM LK) mensyaratkan dibentuknya komite audit yang terdiri dari minimal 3 (tiga) orang anggota yang berasal dari Komisaris Independen dan pihak dari luar perusahaan. Hal ini dilakukan demi tercapainya akuntabilitas yang baik. Mayangsari dan Murtanto (2002) membuktikan bahwa pengumuman pembentukan komite audit yang merupakan hal penting dalam CG direspon secara positif oleh pasar, yang mengindikasikan bahwa pengumuman pembentukan komite audit memiliki kandungan informasi yang menarik minat investor pasar.

Berdasarkan penjelasan di atas, hipotesis yang diajukan adalah sebagai berikut: H1c: Pengungkapan prinsip akuntabilitas berpengaruh terhadap reaksi pasar.

Perusahaan harus mematuhi peraturan perundang-undangan serta melaksanakan tanggung jawab terhadap masyarakat dan lingkungan sehingga dapat terpelihara kesinambungan usaha dalam jangka panjang.

Responsibilitas menunjukkan tanggung jawab manajemen terhadap lingkungan dan menunjukkan bahwa manajemen lingkungan telah dilakukan.

Kondisi tersebut menjadi salah satu parameter khusus bagi investor. Investor memandang kondisi tersebut sebagai signaling theory dalam bentuk informasi lingkungan, yang dapat digunakan sebagai pengambilan keputusan investasi.Shareholder membutuhkan informasi lingkungan untuk pengambilan keputusan investasi, lebih dari itu, informasi tersebut dapat digunakan untuk mengetahui perusahaan-perusahaan yang dipandang sebagai good corporate citizens (Villier dan Staden, 2010). 
Berdasarkan pertimbangan hal-hal tersebut maka ditarik hipotesis sebagai berikut: H1d: Pengungkapan prinsip responsibilitas berpengaruh terhadap reaksi pasar.

Penelitian mengenai hubungan kinerja lingkungan, pengungkapan lingkungan perusahaan dan kinerja keuangan telah dilakukan oleh beberapa peneliti. Dasgupta, Laplante, dan Mamingi (1997) melakukan penelitian respon atas capital market terhadap kinerja lingkungan. Peneliti menggunakan Argentina, chili, Meksiko, dan Filiphina sebagai objek penelitiannya karena merupakan negara-negara dimana pasar modal diyakini bekerja dengan baik dan memiliki kapitalisasi pasar yang relatif tinggi dan meningkat dari waktu ke waktu. Dari hasil penelitiannya ditemukan bahwa pasar saham bereaksi positif terhadap pengumuman atas penghargaan kinerja lingkungan yang lebih baik, dan sebaliknya pasar saham bereaksi negatif terhadap pengumuman atas penghargaan kinerja lingkungan yang buruk.

Al-Tuwaijri et al. (2004) menganalisis hubungan diantara pengungkapan lingkungan, kinerja lingkungan, dan kinerja ekonomi. Pengungkapan lingkungan diukur dengan menggunakan prinsip kinerja lingkungan yang baik yang dikeluarkan oleh Coalition for Environmentally Responsible Economies (CERES): minimize pollutants, conserve resources, and reduce waste. Kinerja lingkungan diukur dengan berdasar pada informasi yang dilaporkan dalam SEC 10-K yang diperoleh dari IRRC database. Hasil penelitian menemukan bahwa environmental performance yang baik secara signifikan berkorelasi dengan kinerja ekonomi yang baik dan juga terhadap environmental disclosure.

Melanjutkan penelitian yang dilakukan oleh Al-Tuwaijri et al. (2004), Suratno et al. (2006) menguji pengaruh kinerja lingkungan terhadap pengungkapan lingkungan dan kinerja ekonomi. Dalam penelitian ini, PROPER digunakan untuk mengukur kinerja lingkungan. Penelitian ini menghasilkan bukti bahwa kinerja lingkungan berpengaruh signifikan terhadap pengungkapan lingkungan, dan juga terhadap kinerja ekonomi. Hasil ini konsisten dengan skenario win-win dan proposisi dari Porter dan Linde (1995) bahwa environmental performance yang baik akan diberikan penghargaan di pasar.

H2 : Informasi kinerja lingkungan berpengaruh terhadap reaksi pasar. 
Budiman dan Supatmi (2009) meneliti tentang dampak ISRA terhadap abnormal return dan TVA. Data yang digunakan dalam penelitian ini adalah data harga penutupan saham harian perusahaan yang menerima ISRA tahun 2005 - 2008, IHSG, dan data yang berasal dari Indonesian Capital Market Directory (ICMD). Berdasarkan penelitian tersebut dihasilkan bahwa terdapat perbedaan abnormal return saham perusahaan yang memenangkan award di seputar tanggal pengumuman ISRA, khususnya pada periode setelah tanggal pengumuman ISRA. Namun penelitian ini menemukan bahwa tidak terdapat perbedaan TVApada perusahaan yang memenangkan ISRA di seputar tanggal pengumuman ISRA.

Villier dan Staden (2010) melakukan survei terhadap shareholder individu tentang pengungkapan lingkungan perusahaan. Peneliti melakukan survey melalui email dan web-based questionnaire survey. Responden yang dipilih adalah asosiasi-asosiasi shareholder di tiga negara, yaitu Australian Shareholders' Association (ASA) di Australia dengan anggota sebanyak 7.700, The United Kingdom Shareholders' Association (UKSA) di Inggris dengan anggota sebanyak 1.700, dan The American Association of Individual Investors (AAII) di Amerika dengan anggota sebanyak 150.000. Hasil penelitian menunjukkan bahwa shareholder membutuhkan informasi lingkungan perusahaan yang detail dan spesifik yang telah diaudit, digunakan untuk mengurangi adanya asimetri informasi. Alasan terbesar shareholder adalah terkait dengan masalah responsibilitas.Responsibilitas menunjukkan tanggung jawab manajemen terhadap lingkungan dan menunjukkan bahwa manajemen lingkungan telah dilakukan. Penelitian ini juga menemukan bahwa shareholder membutuhkan pengungkapan lingkungan perusahaan untuk pengambilan keputusan investasi, lebih dari itu, informasi tersebut dapat digunakan untuk mengetahui perusahaan-perusahaan yang dipandang sebagai good corporate citizens.

H3 : Informasi pengungkapan lingkungan perusahaaan berpengaruh terhadap reaksi pasar.

\section{METODE PENELITIAN}

Populasi dalam penelitian ini adalah perusahaan-perusahaan sektor non keuangan yang terdaftar di BEI untuk tahun 2010 berdasarkan data dari Indonesian Capital Market Directory perusahaan yang terdaftar di BEI selama tahun 2010. 
Penggunaan periode hanya selama satu periode dinilai belum cukup komprehensif dalam mengamati kondisi pasar modal di Indonesia,akan tetapi kelemahan tersebut telah diupayakan diminimalkan dengan mengambil sampel berasal dari keseluruhan sektor industri yang terdaftar di BEI, kecuali Bank dan Lembaga Keuangan, karena tidak memiliki dampak langsung terhadap sosial dan lingkungan. Serta menggunakan annual report sebagai sumber pengungkapan perusahaan.

Terkait dengan informasi kinerja lingkungan yang sifatnya jangka panjang, penggunaan hanya satu periode pengamatan dinilai bisa cukup relevan untuk penarikan kesimpulan karena penilaian aspek kinerja lingkungan tersebut, baik yang berasal dari PROPER dan ISRA, telah dilakukan secara komprehensif selama bertahun-tahun pada periode sebelumnya sehingga laporan yang dikeluarkan pada saat penelitian dilakukan (2010), dinilai telah mencukupi dan mewakili aspek kinerja lingkungan perusahaan.

Pemilihan sampel dilakukan dengan menggunakan metode purposive sampling dengan tujuan untuk mendapatkan sampel yang representatif sesuai dengan kriteria yang di tentukan dan diperoleh sampel sebanyak 129.

\section{Pengukuran Variabel Dependen}

Variabel dependen yang digunakan dalam penelitian ini adalah reaksi pasar yang diproksikan dengan harga saham (stock prices). Harga saham yang dipakai dalam penelitian ini adalah harga saham closing price 30 Desember 2011. Penggunaan harga saham sebagai proksi dari reaksi pasar didasarkan pada penelitian Beaver (1968), dimana publikasi laba memiliki kandungan informasi yang akan direaksi oleh investor melalui harga dan volume perdagangan.

\section{Pengukuran Variabel Independen}

\section{a. Transparansi}

Penilaian dilakukan menggunakan sistem pembobotan, jika perusahaan memenuhi semua kriteria yang diharapkan akan memiliki skor $4 / 4=1$. Beberapa hal yang di uji terkait dengan transparansi dalam penelitian ini adalah kelengkapan laporan keuangan, ketepatan penyampaian laporan keuangan, kelengkapan laporan non keuangan dan kelengkapan laporan RUPS (Keputusan Ketua BPPM-LKNomor: KEP-134/BL/2006). 


\section{b. Kewajaran}

Kewajaran yang dimaksud dalam penelitian ini adalah opini kewajaran laporan keuangan yang diberikan oleh auditor independen pada perusahaan yang bersangkutan. Opini auditor independen tersebut masing-masing akan diberikan bobot (Tristiarini, 2005), yaitu pernyataan tidak memberikan pendapat akan diberikan bobot 1, pendapat tidak wajar akan diberikan bobot 2, pendapat wajar dengan pengecualian akan diberikan bobot 3, pendapat wajar tanpa pengecualian akan diberikan bobot 4 .

\section{c. Akuntabilitas}

Akuntabilitas dalam penelitian ini juga dinilai dari pembentukan Komite Audit, Laporan Dewan Komisaris dan Laporan Direksi, masing-masing akan diberi bobot 1. Apabila tidak sesuai dengan ketentuan di atas, akan diberi bobot 0 (Keputusan Ketua Badan Pengawas Pasar Modal dan Lembaga Keuangan Nomor: KEP-134/BL/2006).

\section{d. Responsibilitas}

Responsibilitas perusahaan dalam penelitian ini diukur dari ada tidaknya pengungkapan atau uraian mengenai keikutsertaan perusahaan dalam kegiatan pelayanan dan program kemasyarakatan, serta pengembangan sumber daya manusia dan lingkungan hidup (Tristiarini, 2005). Jika perusahaan melakukan hal tersebut diatas maka akan diberi bobot 1 jika tidak nol.

\section{e. Informasi Kinerja Lingkungan}

Informasi kinerja lingkungan dalam penelitian ini diproksikan dengan Peringkat Kinerja Perusahaan Dalam Pengelolaan Lingkungan Hidup (PROPER) dikeluarkan oleh Kementerian Lingkungan Hidup (KLH).

Penilaian tersebut didasarkan pada sistem peringkat kinerja PROPER yang memiliki lima peringkat warnayaitu emas, hijau, biru, merah dan hitam. Penilaian dalam variabel ini akan ditentukan bobot dari peringkat yang diperoleh oleh perusahaan tersebut dimana perusahaan yang mendapat peringkat Emas, Hijau, dan Biru akan diberi bobot 1, sedangkan perusahaan yang mendapat peringkat Merah dan Hitam akan diberi bobot nol.

\section{f. Informasi Pengungkapan Lingkungan Perusahaan}

Informasi pengungkapan lingkungan perusahaan diproksikan dengan ISRA. Jika perusahaan memperoleh ISRA, maka akan diberi bobot 1. Jika perusahaan tidak 
menerima Indonesia Sustainability Reporting Award maka akan diberi bobot nol (Budiman dan Supatmi, 2009).

\section{Pengukuran Variabel Kontrol}

\section{a. Earnings}

Pemilihan earnings sebagai variabel kontrol didasarkan atas penelitian Beaver (1968) yang menemukan bahwa investormenggeser posisi portofolio pada saat pengumuman earning dan pergeseran ini konsisten dengan isi laporan. Earning yang digunakan dalam penelitian ini adalah laba bersih setelah pajak (net income).

Studi tentang hubungan pengumuman laba dengan harga saham telah dilakukan oleh beberapa peneliti yaitu Beaver Lambert dan Morse (1980), Foster, Olsen, dan Shevlin (1984), Easton, Harris, dan Ohlson (1992), dan Kothari dan Sloan (1992) yang semuanya menemukan adanya hubungan atas variabel yang di uji.

\section{b. Total Arus Kas}

Variabel total arus kas dipilih untuk digunakan sebagai variabel kontrol karena mengacu pada hasil penelitian empiris yang dilakukan oleh Soesetio (2005) serta Livnat dan Zarowin (1990) tentang kandungan informasi arus kas terhadap reaksi para investor. Penelitian tersebut menghasilkan temuan bahwa secara signifikan pelaporan cash flow statement memiliki kandungan informasi bagi investor. Rumus yang digunakan untuk menghitung total arus kas (Soesetio, 2005) adalah arus kas operasi + arus kas investasi + arus kas pendanaan.

\section{c. Risiko Sistematik (Beta)}

Beta merupakan suatu mekanisme kontrol terhadap risiko yang masih banyak dipakai oleh para manajer portofolio karena beta mempunyai hubungan yang sangat kuat dengan return suatu investasi. Tang dan Shum (2003), dalam penelitiannya menemukan bahwa hubungan antara beta dan return adalah positif signifikan. Penelitian ini menggunakan beta sebagai variabel kontrol, sesuai dengan penelitian yang dilakukan oleh Sayekti dan Wondabio (2007). Beta/ $\beta$ dihitung dengan menggunakan market model (Hartono, 2010; 380) yaitu: $\mathrm{R}_{\mathrm{ij}}=\alpha_{\mathrm{i}}+\beta_{\mathrm{i}} \cdot \mathrm{R}_{\mathrm{Mj}}+\mathrm{e}_{\mathrm{i}, \mathrm{j}}$, dimana $\mathrm{R}_{\mathrm{ij}}$ merupakan Return perusahaan i tahun $\mathrm{j}$, sedangkan $\mathrm{R}_{\mathrm{Mj}}$ adalah Return pasar pada tahun $\mathrm{j}$. 


\section{Pengujian Hipotesis}

Pengujian terhadap hipotesis penelitian dilakukan menggunakan uji regresi linier berganda pada tingkat $\alpha$ sebesar 5\%. Uji regresi yang dilakukan menggunakan pendekatan Ordinary Least Square (OLS) mensyaratkan adanya sifat Best Linier Unbiased Estimation (BLUE) dari model regresi yang terbentuk. Untuk memenuhi persyaratan tersebut maka serangkaian uji asumsi klasik terlebih dahulu dilakukan terhadap keseluruhan model regresi.

Pengujian dilakukan menggunakan model sebagai berikut:

$$
\begin{aligned}
S P_{j}= & \alpha_{0}+\alpha_{1} \text { TRANS }+\alpha_{2} \text { WAJAR }+\alpha_{3} A K U N T+\alpha_{4} R E S P O N+\alpha_{5} \text { PROPER }+ \\
& \alpha_{6} I S R A+\alpha_{7} \text { EARNINGS }+\alpha_{8} \text { TAK }+\alpha_{9} \text { Beta }+e
\end{aligned}
$$

Dimana $S P_{j}$ adalah hargasaham,TRANS adalah prinsip transparansi, WAJAR adalah prinsip kewajaran, AKUNT adalah prinsip, RESPON adalah prinsip responsibilitas, PROPER adalah Peringkat Kinerja Perusahaan Dalam Pengelolaan Lingkungan Hidup, ISRA adalah Indonesia Sustainability Reporting Award, EARNINGS adalah laba bersih setelah pajak, TAK adalah total arus kas, dan beta adalah risiko sistematik suatu saham.

Kaidah pengambilan keputusan pada pengujian hipotesis adalah sebagai berikut:

a. Apabila nilai signifikansi $(p) \leq \alpha$ maka hipotesis alternatif diterima.

b. Apabila nilai signifikansi $(p)>\alpha$ maka hipotesis alternatif ditolak.

\section{HASIL DAN PEMBAHASAN}

\section{Statistik Deskriptif}

Penelitian ini bertujuan untuk menguji pengaruh dari penerapan mekanisme corporate governance melalui penerapan prinsip-prinsipgood corporate governance(GCG), kinerja lingkungan, dan pengungkapan lingkungan pada perusahaan publik terhadap reaksi pasar.

Tabel berikut menyajikan statistik deskriptif dari penerapan prinsip-prinsipgood corporate governance(GCG) dari perusahaan sampel. 
Tabel 1

\begin{tabular}{|l|r|c|c|}
\hline Prinsip GCG & \multicolumn{1}{c|}{ Min } & \multicolumn{1}{c|}{ Max } & \multicolumn{1}{c|}{$\begin{array}{c}\text { Rata- } \\
\text { rata }\end{array}$} \\
\hline Transparan & $44,44 \%$ & $88,89 \%$ & $79,99 \%$ \\
Kewajaran & 1 & 3,94 & 3,94 \\
Akuntabilitas & $50,00 \%$ & $100,00 \%$ & $99,60 \%$ \\
Responsibilitas & $0,00 \%$ & $100,00 \%$ & $81,18 \%$ \\
\hline
\end{tabular}

Pengujian prinsip transparansi menggunakan statistik deskriptif menghasilkan nilai minimum sebesar $44,44 \%$, nilai maksimum sebesar $88,89 \%$, dengan rata-rata sebesar 79,99\%. Berdasarkan rata-rata yang dihasilkan, dapat disimpulkan bahwa perusahaan sampel secara umum sudah mengimplementasikan prinsip-prinsip transparansi dalam laporan keuangan perusahaan.

Pengujian prinsip kewajaran menggunakan statistik deskriptif menghasilkan nilai minimum sebesar 1, yang menunjukkan bahwa terdapat perusahaan sampel yang tidak diberikan pendapat apapun oleh auditor independen, nilai maksimum sebesar 4, dengan rata-rata sebesar 3,94. Nilai rata-rata yang mendekati angka 4 menunjukkan bahwa secara umum perusahaan sampel memperoleh pendapat wajar tanpa pengecualian dari auditor independen.

Pengujian prinsip akuntabilitas menggunakan statistik deskriptif menghasilkan nilai minimum sebesar 50\%, nilai maksimum sebesar $100 \%$, dengan rata-rata mendekati $100 \%$ yang menunjukkan bahwa mayoritas perusahaan sampel telah memiliki kelengkapan prinsip akuntabilitas pada laporan tahunannya.

Pengujian prinsip responsibilitas menghasilkan nilai minimum sebesar $0 \%$, nilai maksimum sebesar $100 \%$, dengan rata-rata sebesar $81,18 \%$. Berdasarkan rata-rata yang dihasilkan, dapat disimpulkan bahwa secara umum perusahaan sampel telah mematuhi penerapan prinsip ini dalam kegiatan operasinya. 
Tabel 2

Hasil Uji Regresi Terhadap Stock Price

\begin{tabular}{|c|c|c|c|}
\hline \multicolumn{4}{|c|}{$+\alpha_{6} P R O P E R+\alpha_{7} U E+\alpha_{8} T A K+\alpha_{9} B e t a+e$} \\
\hline Variabel & Koefisien & t-Hitung & Sign. (p) \\
\hline Konstanta & 4.960 & 5.526 & 0.000 \\
\hline TRANS & 1.809 & 2.641 & $0.009^{*}$ \\
\hline WAJAR & 0.162 & 1.986 & $0.047 *$ \\
\hline AKUN & 0.316 & 5.939 & $0.000^{*}$ \\
\hline RESP & 1.040 & 2.941 & $0.004^{*}$ \\
\hline ISRA & -0.356 & -1.812 & 0.072 \\
\hline PROP & 0.013 & 0.454 & 0.650 \\
\hline EARNING & 0.077 & 2.321 & $0.022^{*}$ \\
\hline TAK & 0.048 & 1.685 & 0.094 \\
\hline BETA & 0.086 & 0.457 & 0.649 \\
\hline $\mathrm{R}^{2}$ & $=0,533$ & & \\
\hline F-hitung & $=17,918$ & & \\
\hline Sign. (p) & $=0,001$ & & \\
\hline
\end{tabular}

* Signifikan secara statistik pada level $\alpha=5 \%$

\section{Hasil Uji Hipotesis I}

Berdasarkan hasil pengujian terhadap hipotesis I, dengan menggunakan keempat proksi mekanisme CG pada perusahaan, penelitian ini berhasil membuktikan adanya pengaruh positif mekanisme CG terhadaphargasaham.Pengujian dengan menggunakan keempat proksi dari mekanisme CG, yang terdiri dari transparansi, kewajaran, akuntabilitas, dan responsibilitas, semuanya konsisten menghasilkan arah pengaruh positif terhadap hargasaham.

Hasil ini mendukung penelitian sebelumnya yang dilakukan oleh Tristiarini (2005) yang menemukan bahwa semua variabel yang diuji yaitu transparansi, kewajaran, akuntabilitas, dan responsibilitas yang merupakan proksi dari mekanisme corporate governancebaik secara signifikansi variabel maupun maupun signifikansi model berpengaruh terhadap reaksi pasar. Selain itu juga konsisten dengan penelitian 
Almilia dan Sifa (2006) yang menyatakan bahwa pengumuman CGPI memiliki kandungan informasi yang ditunjukkan dengan adanya reaksi pasaryang signifikan disekitar tanggal pengumuman.

Berkaitan dengan masalah keagenan, corporate governance diharapkan bisa berfungsi sebagai alat untuk memberikan keyakinan kepada para investor bahwa mereka akan menerima return atas dana yang telah mereka investasikan. Corporate governance berkaitan dengan bagaimana para investor yakin bahwa manajer akan memberikan keuntungan bagi mereka, yakin bahwa manajer tidak akan menggelapkan atau menginvestasikan ke dalam proyek-proyek yang tidak mengutungkan berkaitan dengan dana/kapital yang telah ditanamkan oleh investor, dan berkaitan dengan bagaimana para investor mengkontrol para manajer (Shleifer dan Vishny, 1997). Gompers, Ishii, dan Metrick (2003) memberikan bukti bahwa terdapat hubungan positif antara indeks corporate governance dengan kinerja perusahaan jangka panjang. Tercapainya kinerja perusahaan yang baik tentunya akan berdampak pada ketertarikan investor untuk berinvetasi kepada perusahaan yang mampu menghasilkan kinerja karena akan mampu untuk memberikan return yang menarik.

Corporate governance juga merupakan serangkaian mekanisme yang dapat melindungi pihak-pihak minoritas (outside investors/minority shareholders) dari eksplorasi yang dilakukan oleh para manajer dan pemegang saham pengendali (insider) dengan penekanan pada mekanisme legal (Shleiver dan Vishny, 1997). Oleh karena itu, kontrak yang baik antara investor dan manajer adalah kontrak yang mampu menjelaskan spesifikasi-spesifikasi apa sajakah yang harus dilakukan manajer dalam mengelola dana para investor, dan spesifikasi tentang pembagian return antara manajer dengan investor.

Hasil pengujian yang konsisten menunjukkan adanya pengaruh positif dari keempat proksimekanisme CG tersebut di atas, menunjukkan bahwa untuk dapat menghasilkan kinerja perusahaan yang baik, dalam pengelolaannya perusahaan harus menerapkan mekanisme CG yang direfleksikan dengan pilar-pilar good corporate governance tersebut. Sehingga dengan adanya image bahwa perusahaan telah berkinerja baik, maka akan menimbulkan sentimen positif dari investor yang pada akhirnya akan meningkatkan harga saham. Selain itu laporan keuangan ataupun laporan tahunan masih merupakan media yang paling tepat untuk menyampaikan informasi mengenai penerapan corporate governance di perusahaan. 


\section{Hasil Uji Hipotesis II}

Berdasarkan hasil pengujian terhadap Hipotesis II, penelitian ini tidak berhasil membuktikan adanya pengaruh kinerja lingkungan terhadap reaksi pasar yang diproksikan dengan harga saham. Hasil penelitian ini mendukung Brammer et al (2005) yang menemukan bahwa perusahaan dengan skor kinerja sosial yang lebih tinggi, justru cenderung memberikan tingkat pengembalian yang rendah, sedangkan perusahaan dengan skor kinerja lingkungan yang rendah atau nol mampu memberikan tingkat pengembalian yang tinggi. Sebaliknya hasil penelitian ini tidak memberikan dukungan pada penelitian yang dilakukan oleh Dasgupta et al (1997) yang menemukan bahwa pasar saham bereaksi positif terhadap pengumuman atas penghargaan kinerja lingkungan yang lebih baik, dan sebaliknya pasar saham bereaksi negatif terhadap pengumuman atas penghargaan kinerja lingkungan yang buruk yang berarti bahwa kinerja lingkungan berpengaruh terhadap reaksi pasar.

Hasil pengujian yang dilakukan menunjukkan bahwa investor masih belum tertarik untuk menggunakan kinerja lingkungan (PROPER) dalam pengambilan keputusan bisnis, sehingga tidak mampu untuk meningkatkan harga saham.Tidak terbuktinya hipotesis ke dua ini ada kemungkinan masih banyak investor yang belum memahami konsep kinerja lingkungan (PROPER) maupun manfaatnya sehingga tidak ditemukan adanya pengaruh yang signifikan terhadap reaksi pasar yang diproksikan dengan harga saham. Padahal, jika kita lihat penelitian yang dilakukan oleh Al-Tuwaijri et al.(2004) dan Suratno et al.(2006) yang menemukan bahwa environmental performance yang baik secara signifikan berpengaruh terhadap kinerja ekonomi yang baik dan juga terhadap environmental disclosure,artinya dengan environmental performance yang baik akan diberi penghargaan di pasar (Porter dan Linde, 1995), hal tersebut seharusnya akan meningkatkan minat investor.

\section{Hasil Uji Hipotesis III}

Berdasarkan hasil pengujian terhadap Hipotesis III, penelitian ini tidak berhasil membuktikan adanya pengaruh pengungkapan lingkungan perusahaan terhadap reaksi pasar yang diproksikan dengan harga saham. Hasil penelitian ini konsisten dengan penelitian yang dilakukan oleh Anderson-Weir (2010) yang menemukan bahwa 
perusahaan yang memiliki rangking yang lebih buruk justru menimbulkan reaksi negatif pada pasar.

Hasil penelitian ini tidak konsisten dengan penelitian sebelumnya yaitu yang dilakukan oleh Budiman dan Supatmi (2009) yang menemukan bahwa terdapat perbedaan hargasaham perusahaan yang memenangkan award di seputar tanggal pengumuman ISRA, khususnya pada periode setelah tanggal pengumuman ISRA. Hasil ini juga tidak mendukung penelitian Villier dan Staden (2010) yang menyatakan bahwa shareholder membutuhkan pengungkapan lingkungan perusahaan untuk pengambilan keputusan investasi. Adanya minat yang besar dari para investor terhadap suatu saham tertentu, maka akan berdampak pada peningkatan harga saham tersebut.

Hasil ini mengindikasikan bahwa pengungkapan lingkungan (publikasi ISRA), dalam jangka panjang masih belum sepenuhnya dijadikan preferensi dalam menentukan keputusan investasi. Adanya reaksi pasar yang cukup signifikan di sekitar ranggal pengumuman ISRA pada penelitian Budiman dan Supatmi (2009) menunjukkan bahwa investor hanya merepon sesaat atas pengumuman tersebut, yang hanya menunjukkan adanya aksi profit taking dalam jangka pendek. Sedangkan, ketika pengujian diperluas dalam jangka panjang, hasil penelitian tidak mampu membuktikan adanya korelasi yang signifikan antara informasi ISRA terhadap perubahan harga saham perusahaan.

\section{Hasil Uji Variabel Kontrol}

Pengujian terhadap ketiga veriabel kontrol yaitu earning, total arus kas, dan risiko sistematik menunjukkan bahwa hanya variabel earning yang berpengaruh signifikan terhadap reaksi pasar yang diproksikan dengan harga saham. Hasil ini mendukung Bernard dan Stober (1989), dan Brown, Finn, dan Hancock (1977) yang menemukan bukti adanya pengaruh positif antara earning terhadap harga saham. Hasil penelitian ini tidak mendukung Soesetio (2005) dan Livnat dan Zarowin (1990) tentang kandungan informasi arus kas terhadap reaksi para investor, bahwa secara signifikan pelaporan cash flow statement memiliki kandungan informasi bagi investor. Penelitian ini juga tidak mendukung Tang dan Shum (2003) yang menemukan bahwa hubungan antara beta dan return adalah positif signifikan.

Hasil pengujian terhadap earning menunjukkan bahwa informasi earning dalam laporan keuangan dapat memberikan sinyal yang positif mengenai prospek dan kinerja 
perusahaan di masa depan. Dengan adanya pertumbuhan earning yang terus meningkat dari tahun ke tahun, akan memberikan sinyal yang positif tentang kelangsungan hidup perusahaan, disebabkan informasi earning bisa digunakan untuk menilai kinerja manajemen, membantu mengestimasi kemampuan laba yang representatif dalam jangka panjang, meramalkan laba, dan menaksir resiko dalam berinvestasi.

Hasil pengujian terhadap total arus kas mengindikasikan bahwa informasi laba memberikan informasi incremental di banding aliran kas. Hasil yang sama juga ditemukan oleh Parawiyati dan Baridwan (1998) yang menyimpulkan bahwa prediktor laba mempunyai kandungan informasi yang lebih besar dibanding aliran kas. Selain itu, fakta dan temuan dari beberapa penelitian sebelumnya menunjukkan bahwa pengujian menggunakan informasi total arus kas hanya relevan untuk pengambilan keputusan dalam jangka pendek, yang merupakan refleksi dari reaksi sesaat dari pelaku pasar terhadap informasi yang beredar di pasar modal.

Hasil pengujian terhadap risiko sitematik (beta) memberikan informasi bahwa dalam jangka pendek (di sekitar tanggal pengumuman laporan tahunan perusahaan), investor masih belum menjadikan risiko sistematik sebagai preferensi dalam menentukan perubahan strategi berinvestasi. Dalam pembuatan keputusan investasi, investor memerlukan ukuran risiko sistematik yang akurat dan tidak bias. Hal ini sangat penting bagi investor, sebagai dasar untuk memperkirakan besarnya risiko maupun return investasi dimasa depan. Dengan melihat perilaku koefisien beta dari waktu ke waktu, investor akan memperkirakan besarnya risiko sistematik pada masa yang akan datang. Berdasarkan pertimbangan tersebut, secara umum menjadi sangat tidak mungkin apabila perilaku koefisien beta yang merupakan data historis yang membutuhkan waktu pengamatan yang panjang, bisa digunakan sebagai preferensi dalam event window yang relatif pendek, hanya di sekitar tanggal publikasi laporan tahunan perusahaan.

\section{KESIMPULAN DAN SARAN}

\section{Kesimpulan}

Penelitian ini bertujuan untuk menguji pengaruh mekanisme corporate governance (yang diproksikan dengan transparansi, kewajaran, akuntabilitas, dan responsibilitas), kinerja lingkungan perusahaan dan pengungkapan lingkungan 
perusahaan terhadap reaksi pasar yang diproksikan dengan harga saham pada Bursa Efek Indonesia. Penelitian ini menggunakan tiga variabel kontrol yaitu earnings, total aruskas, dan risikosaham yang diproksikandengan beta.

Berdasarkan hasil pengujian yang telah dilakukan menunjukkan bahwa mekanisme corporate governance memiliki pengaruh signifikan terhadap reaksi pasar yang diproksikan dengan harga saham. Hasil ini mendukung penelitian sebelumnya yang dilakukan oleh Tristiarini (2005). Pengujian yang dilakukan terhadap informasi kinerja lingkungan yang diproksikan dengan PROPER dan informasi pengungkapan lingkungan yang diproksikan dengan ISRA tidak mampu memberikan pengaruh yang signifikan terhadap reaksi pasar yang diproksikan dengan harga saham. Hasil penelitian ini mendukung Brammer et al (2005) dan konsisten dengan Anderson-Weir (2010).

Hasil penelitian ini mengindikasikan bahwa para investor masing menggunakan mekanisme corporate governance sebagai preferensi dalam pengambilan keputusan investasi, tetapi aspek sosial yaitu informasi kinerja lingkungan (PROPER) dan informasi pengungkapan lingkungan perusahaan (ISRA) bukan preferensi yang baik dalam berinvestasi, karena para investor memandang sebagai tindakan yang akan mengurangi profit perusahaan.

Penelitian ini masih memiliki beberapa keterbatasan. Pertama, Penelitian hanya menggunakan periode penelitian yang relatif pendek, yaitu satu tahun (2010). Hal tersebut dikhawatirkan dapat menyebabkan penarikan kesimpulan kurang bisa digeneralisasikan karena adanya fluktuasi kinerja perusahaan sampel pada saat penelitian. Selain itu juga adanya informasi tentang kinerja lingkungan dan pengungkapan lingkungan kemungkinan baru akan direspon oleh pasar dalam jangka panjang. Kedua, Pengujian atas kinerja lingkungan dan pengungkapan lingkungan yang dilakukan pada Bursa Efek Indonesia menunjukkan bahwa pasar tidak merespon adanya informasi tersebut, yang disebabkan karena pasar belum memahami konsep dan manfaatnya. Dikhawatirkan jika kedua variabel tersebut diterapkan pada penelitian yang akan datang, akan menghasilkan temuan dimana para investor masih belum memahami konsep dan manfaat dari kinerja lingkungan dan pengungkapan lingkungan perusahaan. Ketiga, hasil koefisiendeterminasi yang dihasilkantergolongmasihrendah. Kondisi ini menunjukkanmasihbanyakfaktorlain yang memengaruhireaksipasar dan belumdimasukkandalam model penelitian. 
Berdasarkan kesimpulan dan keterbatasan tersebut, beberapa saran dapat digunakan untuk penelitian yang akan datang. Pertama, Penelitian selanjutnya bisa dikembangkan dengan menggunakan periode yang lebih panjang. Hal tersebut perlu dilakukan dengan pertimbangan untuk meminimalkan pengaruh fluktuasi kinerja perusahaan akibat perubahan kondisi perekonomian dan juga untuk mengetahui respon pasar yang sebenarnya atas informasi yang bersifat sosial yaitu kinerja lingkungan dan pengungkapan lingkungan perusahaan. Kedua, Penelitian selanjutnya yang akan meneliti terkait informasi kinerja lingkungan dan pengungkapan lingkungan perusahaan sebaiknya menggunakan pasar modal besar karena para investornya telah memahami konsep dan manfaat dari informasi kinerja lingkungan dan pengungkapan lingkungan perusahaan dalam pengambilan keputusan, seperti New York Stock Exchange (NYSE) dan National Association of SecuritiesDealersAutomatedQuotation (NasdaQ) di Amerika, Tokyo Stock Exchangedi Jepang dan London Stock exchange di Inggris. Ketiga, Penelitian selanjutnya dapat dikembangkan dengan melakukan pengembangan dari modelyang telah diangkat pada penelitian ini, dengan harapan mampu memperbaiki hasil koefisien determinasi yang dihasilkan. Variabel fundamental keuangan, yang memang selama ini masih populer di kalangan investor tanah air, dapat ditambahkan pada penelitianyang akan datang, sehingga akan menghasilkan penelitian yang komprehensif karena telah mengadopsi 3 (tiga) aspek penting yaitu internal control (mekanisme CG), sosial dan lingkungan, serta fundamental keuangan suatu perusahaan.

\section{DAFTAR PUSTAKA}

Almilia, Luciana Spica dan Lailul L.Sifa. 2006. Reaksi Pasar Publikasi Corporate Governance Perception Index (CGPI) pada Perusahaan yang Terdaftar di Bursa Efek Jakarta. Simposium Nasional Akuntansi IX, Padang.

Al-Tuwaijri, Sulaeman A., Theodore E. Christensen, and K.E. Hughes II. 2004. The

Relations among Environmental Disclosure, Environmental Performance, and Economic Performance: A Simultaneous Equation Approach. Accounting, Organizations and Society, 29: 447-471.

Anderson-Weir, Charles H. 2010. How Does the Stock Market React to Corporate Environmental news. Undergraduate EconomicReview: Vol. 6: Iss. 1, Article 9.

Arifin, Zaenal. 2003. Pengaruh Corporate Governance terhadap Reaksi dan Volume 
Perdagangan Pada Saat Pengumuman Earnings. Simposium Nasional Akuntansi VI, Surabaya.

Ball, Ray dan Philip Brown. 1968. An Empirical Evaluation of Accounting Income Number. Journal of Accounting Research, V ol. 6, No. 2: 159 - 178.

Parawiyati dan Zaki Baridwan. 1998. Kemampuan Laba dan Arus Kas dalam Memprediksi laba dan Arus Kas Perusahaan Go publik di Indonesia. Jurnal Riset Akuntansi Indonesia, Vol.1, No.1, Januari.

Bartov, Ell. 1993. The Timing of Asset Sales and Earning Manipulation. The Accounting Review, Vol. 68: 840-855.

Beattie, Vivien, Stephen Brown, David Erwers, Brian John, Stuart Manson, Dylan Thomas, and Michael Turner. 1994. Extraordinary Items and Income Smoothing: A Positive Accounting Approach. Journal of Business Finance and Accounting: 791811.

Beaver, W. H. 1968. The Information Content of Annual Earning Announcement. Empirical Research in Accounting: Selected Studies. Supplement to Journal of Accounting Research: 67 - 92.

Beaver, W. H., Richard Lambert, and Dale Morse. 1980. The Information Content of Security Prices. Journal of Accounting anf Economics, 2: 3 - 28.

Belkaoui, Ahmed. 1976. The Impact of The Disclosure of The Environmental Effects of Organizationl Behavior on The Market. Financial Management: 26-31.

Bernard V., and T. Stober. 1989. The Nature and Amount of Information Reflected in Cash Flows and Accruals. The Accounting Review, 64 (October): 624-952.

Black, Bernard. 2001. The Corporate Governance Behavior and Market Value of Russian Firms. Emerging Market Review, 2: 89-108.

Brammer, Stephen, Chris Brooks, and Stephen Pavelin. 2005. Corporate Social Performance and Stock Returns: UK Evidence from Disaggregate Measures,Social Science Research Network, SSRN-id739587. Retrieved 03 Juli, 2012.

Brown, Lawrence D., and Marcus L. Caylor. 2006. Corporate Governance and Firm Valuation. Journal of Accounting and Public Policy, 25: 409-434.

Brown, P., D., Finn, F., and Hancock, P. 1977. Dividend Changes, Earnings Reports and Share Prices: SomeAustralian Findings. Australian Journal ofManagement, 2, 127 147. 
Budiman, Ferry dan Supatmi. 2009. Pengaruh Pengumuman Indonesia Sustainability Reporting Award (ISRA) terhadap AbnormalReturn dan VolumePerdaganganSahamStudiKasus pada PerusahaanPemenang ISRA Periode 2005-2008. Simposium Nasional Akuntansi XII, Palembang.

Dasgupta, S., Benoit Laplante, andNlandu Mamingi. (1997). Pollution and CapitalMarkets in DevelopingCountries. Journal of Environmental Economics and Management, 42, 310-335.

Easton, Peter D., Trevor S. Harris, and James A. Ohlson. 1992. Accounting EarningsCan ExplainMost of SecurityReturns: The Case of LongEvent Windows. Journal of Accounting and Economics, Vol 15: 119-142.

Elkington, John. 1997. Cannibals with Forks, the Tripple Bottom Line of Twentieth Century Business.Capstone: Oxford.

Fama, E. F., and M. C. Jensen. 1983. The Separation of Ownership and Control. Journal of Law and Economics, 26: 301-328.

Fatmawati, Sri dan Marwan Asri. 1999. Pengaruh Stock Split Terhadap Likuiditas Saham yang Diukur Dengan Besarnya Bid-Ask Spread Di Bursa Efek Jakarta. Jurnal Ekonomi Dan Bisnis Indonesia, Vol.14, No.4: 93-110.

Foster, G. 1986. Financial Statement Analysis. 2nd Edition. Prentice-Hall. Englewood Cliffs. New Jersey.

Foster, G. C. Olsen, and T. Shevlin. 1984. Earnings Releases, Anomalies, and the Behavior of Security Returns. The Accounting Review: 574-603.

Gompers, Paul,Joy Ishii and Andrew Metrick. 2003. Corporate Governance And Equity Prices. The Quarterly Journal of Economics, MIT Press, Vol. 118(1): 107-155.

Hartono, Jogiyanto. 2010. Teori Portofolio dan AnalisisInvestasi, BPFE Yogyakarta, Edisi Ketujuh, Yogyakarta.

Hendricksen, Eldon S., and Michael F. Van Breda. 1992. Accounting Theory. Fifth Edition. Richard D. Irwin, Boston.

Ismail, Rina Fadhila., Roshayani Arshad, and Suaini Othman. 2012. The Influence of Voluntary Risk Disclosure on Firm Market Value. 3rd International Conference on Business and Economic Research.

Jensen, Michael C.,and W. H. Meckling. (1976). Theory of The Firm: Managerial Behavior, Agency Theory and Ownership Structure. Journal of Financial 
Economic, Vol. 3, No. 4: 305 - 360 .

Junaedi, Dedi. 2005. Dampak Tingkat Pengungkapan Informasi Perusahaan terhadap Volume Perdagangan dan Return Saham. Jurnal Akuntansi dan Keuangan Indonesia, Vol. 2, No. 2: 1 - 28.

Klapper, Leora F., and Inessa Love. 2004. Corporate governance, Investor Protection, and Performance in Emerging Markets. Journal of Corporate Finance, 10: 703-728.

Komite Nasional Kebijakan Governance (KNKG). 2006. Pedoman Umum Good Corporate Governance Indonesia.

Kothari, S.P., and Richard G. Sloan. 1992. Information In Prices About Future Earnings: Implications For Earnings Response Coefficients. Journal of Accounting and Economics, Vol. 15: 143-171.

La Porta, Rafael, Florencio Lopez De Silanes, Andrei Shleifer, and Robert Vishny, 2002. Investor Protection and Corporate Valuation. The Journal of Finance, Vol. LVII, No. 3: 1147-1169.

Livnat, J., andPaul Zarowin. 1990. The Incremental Information Content of Cash Flow Components. Journal of Accounting and Economics, 13: 25-46

Mayangsari, Sekar dan Murtanto. 2002. Reaksi Pasar Modal Indonesia terhadap Pembentukan Komite Audit. Proceeding Simposium Surviving Strategies to Cope With the Future. Universitas Atmajaya. Yogyakarta.

Meiden, Carmel. 2008. Pengaruh Opini Audit terhadap Return dan Volume Perdagangan Saham. Akuntabilitas, Vol. 7, No. 2: 109 - 113.

Morck, Randall. 1988. Management Ownership and Market Valuation: An Empirical Analysis. Journal of Finance Economics, 20: 293-315.

Neal, Robert, and Philip L. Cochran. 2008. Corporate Social Responsibility, Corporate Governance, and Finance Performance: Lesson from Finance, Business Horizons (2008) 51: 535 - 540.

Patten, Dennis M. 1990. The Market Reaction to Social Responsibility Disclosures: The Case of the Sullivan Principles Signings Accounting, Orgizations and Society. Oxford, Vol. 15, Iss. 6: 575.

Porter, M. and Claas Van DerLinde. 1995. Green and Competitive: Ending the Stalemate. Harvard Business Review, Vol. 73(5): 120-134.

Sayekti, Yosefa dan LudovicusSensiWondabio. 2007. Pengaruh CSR Disclosure 
terhadap Earning Response Coefficient (Studi Empiris pada Perusahaan yang Terdaftar di Bursa Efek Jakarta). Simposium Nasional Akuntansi X, Makassar.

Scott, W.R. 2000. Financial Accounting Theory. Second Ed., Prentice-Hall International, Inc.

Soesetio, Yuli. 2005. Analisis TambahanKandunganInformasiLaporanArus Kas. Jurnal Eksekutif, Vol. 2, No. 2: 144-153.

Shleifer, Andrei dan R. W. Vishny. 1997. A Survey of Corporate Governance, The Journal of Finance, Vol. LIL, No. 2, June.

Suratno, Ignatius Bondan., Darsono dan Siti Mutmainah. 2006. Pengaruh Environmental Performance terhadap Environmental Disclosure dan Economic Performance. Simposium Nasional Akuntansi IX, Padang.

Tang, Gordon Y.N., and Wai C. Shum. 2003. The Conditional Relationship Between Beta and Return: Recent Evidence from International Stock Markets. International Business Review 12: 109-126.

Tristiarini, Nila. 2005. Pengaruh Penerapan Corporate Governance terhadap Abnormal Return Pada Saat Pengumuman Laporan Keuangan 2003. Tesis. Universitas Diponegoro, Semarang.

Villiers, Charl de and Chris J van Staden. 2010. Shareholders Requirements for Corporate Environmental Disclosures: A Cross Country Comparison. The British Accounting Review. 